\title{
FACTORS AFFECTING COLONIZATION AND ABUNDANCE OF Aphis gossypii GLOVER (HEMIPTERA: APHIDIDAE) ON OKRA PLANTATIONS
}

\author{
Fatores que afetam a colonização e abundância de Aphis gossypii glover \\ (Hemiptera: Aphididae) em plantações de quiabeiro
}

Germano Leão Demolin Leite ${ }^{1}$, Marcelo Picanço², José Cola Zanuncio ${ }^{3}$, Marcos Rafael Gusmão ${ }^{4}$

\begin{abstract}
The control of Aphis gossypii Glover (Hemiptera: Aphididae) on okra Abelmoschus esculentus (L.) (Malvaceae) consist primarily in the use of insecticides, due to the lack of information on other mortality factors. The objective of this study was to determine the effects of predators and parasitoids, height of canopy, plant age, leaf areas, organic compounds leaves, levels of leaf nitrogen and potassium, density of leaf trichomes, total rainfall and median temperature on attack intensity of $A$. gossypii on two successive A. esculentus var. Santa Cruz plantations. Monthly number estimates of A. gossypii and natural enemies (visual inspection) occurred on bottom, middle and apical parts of 30 plants/plantation (one leaf/plant). Plants senescence, leaf areas and natural enemies, mainly Adialytus spp., spiders and Coccinellidae, were some of the factors that most contributed to aphid reduction. A higher number of aphids was found on the bottom part than medium and apical parts of okra plants. Total rainfall can reduce the aphid population. Trichomes non-glandular or low density, organic compounds leaves and levels of $\mathrm{N}$ and $\mathrm{K}$ were not important for reducing aphid population.
\end{abstract}

Index terms: Abelmoschus esculentus, aphid, natural enemies, leaf area, nitrogen.

\section{RESUMO}

O controle de Aphis gossypii Glover (Hemiptera: Aphididae) em quiabeiro Abelmoschus esculentus (L.) (Malvaceae) consiste principalmente no uso de inseticidas, em virtude da falta de informação sobre outros fatores de mortalidade. Objetivou-se com este estudo determinar os efeitos de predadores e parasitóides, altura de dossel, idade da planta, área foliar, compostos orgânicos foliares, níveis de nitrogênio e potássio, densidade de tricomas, pluviosidade e temperatura na intensidade de ataque de A. gossypii em dois cultivos sucessivos de Abelmoschus esculentus var. Santa Cruz. Estimou-se, mensalmente, o número de A. gossypii e de inimigos naturais (inspeção visual) ocorridos nas folhas (uma folha/planta) localizadas nas partes basal, mediana e apical de 30 plantas/ plantação. Os fatores que mais contribuíram com a redução da população de pulgões foram a senescência de plantas, área foliar e inimigos naturais, principalmente Adialytus spp., aranhas e Coccinellidae. Maior número de pulgões foi observado na parte basal que na mediana e apical de plantas de quiabeiro. A pluviosidade total pode reduzir a população de pulgões. Tricomas tectores (nãoglandulares) ou baixa densidade destes, compostos orgânicos foliares e níveis de $\mathrm{N}$ e de $\mathrm{K}$ não foram importantes para a redução da população de pulgões.

Termos para indexação: Abelmoschus esculentus, afídeos, inimigos naturais, área foliar, nitrogênio.

(Received in november 22, 2005 and approved in july 28, 2006)

\section{INTRODUCTION}

The okra, Abelmoschus esculentus (L.) (Malvaceae), is an annual plant that can reach three meters in height, originated from hot areas of Africa and it can produce up to 40 ton/hectare (FILGUEIRA, 2000). The aphid Aphis gossypii Glover (Hemiptera: Aphididae) is an important pest of this crop and it can cause economic damage to plants by feeding on the sap and coating its leaves with honeydew, which facilitates growth of sooty mold (PATEL et al., 1997; SATAR et al., 2005). This insect has been controlled primarily with insecticides mainly due to a lack of knowledge on factors affecting its population growth. Such information could be used in predicting attack of this pest which in turn could reduce economic losses to okra plants (DENT, 1995).

Several factors can influence the occurrence of aphid populations and the fertilization is the most important one (CISNEROS \& GODFREY, 2001; SLOSSER et al., 2004). An excess of nitrogen $(\mathrm{N})$ or deficiency of potassium $(\mathrm{K})$ can lead to higher accumulation of amino acids which in turn can cause higher attack rate by sucking insects (JANSSON \& EKBOM, 2002). Also, plant phenology such as leaf position on plant canopy, plant age, leaf areas, and trichomes besides natural enemies and weather can influence population of A. gossypii (CHAU et al., 2005;

\footnotetext{
'Engenheiro Agrônomo D.Sc.; Professor do Núcleo de Ciências Agrárias/NCA - Universidade Federal de Minas Gerais/UFMG - Cx. P. 135 - $39.404-006$ Montes Claros, MG - gldleite@ufmg.br

2Engenheiro Agrônomo D.Sc.; Professor da Universidade Federal de Viçosa/UFV - 36571-000 - Viçosa, MG - picanco@mail.ufv.br

${ }^{3}$ Engenheiro Florestal PhD; Professor da Universidade Federal de Viçosa/UFV - zanuncio@mail.ufv.br

${ }^{4}$ Engenheiro Agrônomo D.Sc. Universidade Federal de Viçosa/UFV - 36.570-000 - Viçosa, MG.
} 
MEN et al., 2004; RHAINDS \& MESSING, 2005; SANTOS et al., 2003; SATAR et al., 2005; SECHSER et al., 2002; SOGLIA et al., 2002, 2003). Since effects of such factors on okra plants are little known, the aim of the present investigation was to evaluate the effects of predators, parasitoids, leaf organic compounds, levels of $\mathrm{N}$ and $\mathrm{K}$, leaf trichome density, canopy height, plant age, leaf areas, rainfall and temperature on attack intensity of $A$. gossypii on successive okra plantations under field conditions.

\section{MATERIAL AND METHODS}

This experiment was carried out in two okra plantations of Abelmoschus esculentus var. Santa Cruz from Guidoval, Minas Gerais, Brazil. Fertilization and cultural practices utilized for okra in this study have been described by Filgueira (2000) and the plants were not sprayed with insecticides. The two okra plantations were $50 \mathrm{~m}$ apart (with gramineae of small height between plantations); each plantation comprised 3.6 ha with 10,000 plants $0.30 \mathrm{~m}$ apart on the row, $1.2 \mathrm{~m}$ between rows. The 10 peripheral rows and 40 plants on each end of the row were not considered, leaving a useful area of 2.7 ha, i.e. 30 rows, $176 \mathrm{~m}$ long. The first, the 16-day-old plantation, was evaluated from March $1^{\text {st }}$ to June $30^{\text {th }} 1999$ and the second, the 50-day-old plantation, was evaluated from July $1^{\text {st }}$ to November $30^{\text {th }}$ 1999. After the final evaluation, the first plantation was eliminated. These plantations were far from other vegetable crops (i.e., Brassica oleracea L. var. capitata, Cucumis sativus L., Cucurbita pepo L., Lycopersicon esculentum Mill., Phaseolus vulgaris L., Solanum melongena L.), at least $1.000 \mathrm{~m}$.

Monthly number estimates of A. gossypii (adults + nymphs), predators (adults + larvae) and parasitoids (adults), both leaf surfaces (adaxial and abaxial), were obtained by visual inspections (HOROWITZ, 1993) on the bottom, middle and apical parts of 30 plants/plantation (one leaf/plant part). The first expanded leaf/apex of the plant was put on a $34 \times 26 \times 5 \mathrm{~cm}$ white tray to collect the arthropods with an aspirator or tweezer and placed individually in $8 \times 2 \mathrm{~cm}$ glass flasks, containing $70 \%$ ethanol for identification.

One apical leaflet from each part of the canopy of nine plants/plantation was collected, monthly, on three occasions, and placed in white transparent plastic bags, sealed and stored in $70 \%$ ethanol, for analysis. Leaflets were cleared for 2 hours in $10 \% \mathrm{NaOH}$ and 18 hours in sodium hypochloride (20\%). After washing and during the dehydration, leaflets were stained for $3 \mathrm{~min}$ in fast green and slides were prepared using Canadian balsam. The number of adaxial and abaxial trichome was counted under a light microscope on the apical leaflet's median part. In each sample, six fields of $0.60 \mathrm{~mm}^{2}$, each between the median vein and the margin were analyzed. The trichomes were classified as glandular or non-glandular. Leaf areas were determined on the bottom, middle and apical parts of 45 plants (one leaf/plant) using a leaf area meter LI-COR model LI-3000 (Lincoln, Nebraska, USA).

One expanded leaf from the apex of 15 plants/ plantation was monthly collected and taken to the laboratory for $\mathrm{N}$ and $\mathrm{K}$ determination. These leaves were placed in Kraft paper bags, dried in a forced air circulation oven at $67^{\circ} \mathrm{C}$ for three days and then ground in a Wiley mill (20 mesh). Potassium was determined with a Flame Photometer (Coleman, Model 22) and nitrogen analyzed by Nessler method (JACKSON, 1958). Three replications, consisting of five leaves in each evaluation, were made for each collection of two plantations.

For gas chromatography/mass spectrometry (GC/ MS) analysis, fully expanded apical leaves of 15 plants/ plantation were sampled monthly, placed in plastic bags, sealed, and transported to the laboratory. A 10-g latch was cut with scissors, immersed in $100 \mathrm{~mL}$ of bidistilled hexane for $24 \mathrm{~h}$, dehydrated with anhydrous $\mathrm{Na}_{2} \mathrm{SO}_{4}$, evaporated to dryness at $30^{\circ} \mathrm{C}$ in a rotatory evaporator, sealed in nitrogen and stored in a freezer until being analized. One evaluation was made for each collection of two plantations.

The hexane extracts were analyzed by an autosampler Shimadzu, Model QP 5000, a computer-based system to accumulate data and a mass spectra database (John Wiley) with 160,000 compounds. The oven was programmed to develop a temperature gradient, from $33^{\circ} \mathrm{C}$ to $80^{\circ} \mathrm{C}$, at $20^{\circ} \mathrm{C} / \mathrm{min}$, and when a higher temperature was achieved, a new gradient from $80^{\circ} \mathrm{C}$ to $250^{\circ} \mathrm{C}$ was carried through at $5^{\circ} \mathrm{C} / \mathrm{min}$. The injector and transfer line temperatures were of $180^{\circ} \mathrm{C}$ and $250^{\circ} \mathrm{C}$, respectively. The split ratio was five, with $\mathrm{He}$ as the carrier gas. All analyses were carried out on a fused capillary column of $30 \mathrm{~m} / 0.25$ $\mathrm{mm}$ and film thickness of $0.25 \mathrm{~mm}$ (J \& W Scientific, USA). The ionization voltage was $70 \mathrm{eV}$ and the mass spectrometer scanned between 40 - 550 amu (atomic mass unit). Retention times for peaks with total ion current (TIC) higher than $4 \times 10^{5}$ ions/sec were recorded with a minimum area for peak integration of 400,000 ions/sec. The compounds were identified using the mass spectral database and only compounds with a similarity index (SI) greater than $83 \%$ were considered as positive identifications. Further identification through standards was not attempted. 
Guidoval's climatic data, total rainfall and median temperature (minimum + maximum/2), were read daily from a pluviometer and thermometer, installed in the field at the beginning of the experiment. Canopy height effects on predators, parasitoids, trichome densities, leaf areas, and A. gossypii were verified by variance analyses and the Tukey's multiple range test $(\mathrm{P}<0.05)$. Regression analyses $(\mathrm{P}<0.05)$ were used to evaluate the relationships of predators, parasitoids, organic compounds in the leaves, leaf $\mathrm{N}$ and $\mathrm{K}$ levels, leaf trichome density, plant age, rainfall and temperature with the A. gossypii number on okra plants.

\section{RESULTS}

The aphid A. gossypii presented higher number of apterous and winged individuals during the months of May (first plantation) and September (second plantation) on okra plants (Figure $1 \mathrm{~A}, \mathrm{~B}$ ) when those plants were 76 and 110 days old, respectively. A lower aphid attack was observed in the second (35.0/leaf) okra plantation, planted $50 \mathrm{~m}$ apart from the first (485.0/leaf) (Figure $1 \mathrm{~A}, \mathrm{~B}$ ). Population increase of apterous aphids caused the appearance of winged individuals of this species for dispersal (Figure 1 A, B). Higher number of apterous forms of this insect was observed on leaves with larger areas, which were located in medium, bottom and apical parts of the plant canopy (Table 1). Lower populations were recorded after leaves were colonized and winged forms of this insect for dispersal were observed (Figure $1 \mathrm{~A}, \mathrm{~B}$ ).

Adialytus spp. (Hymenoptera: Braconidae), which are aphid parasitoids, presented population peaks in June and October whereas the ladybird beetles [Cycloneda sanguinea (L.) and Scymnus sp. (Coleoptera: Coccinellidae)] had higher populations in April and October and the spiders [Cheiracanthium inclusum (Hentz) (Miturgidae), Dictyna sp. (Dictynidae), Eustala sp. (Araneidae), Lyssomanes sp. (Salticidae), Misumenops spp. (Thomisidae) and Theridiidae] in June and October (Figure $1 \mathrm{C}, \mathrm{D}, \mathrm{E}, \mathrm{F}, \mathrm{G})$. At the beginning of the first and second plantations, number of natural enemies (initial colonization phase) was reduced (Figure 1 C, D, E, F, G). Adialytus spp. attacked more than $55 \%$ of $A$. gossypii in the last plantation (Figure 1 D). Significant relationships $(\mathrm{P}<0.05)$ with densities of Adialytus spp. $\left(\mathrm{y}=0.22+0.004 \mathrm{x} ; \mathrm{R}^{2}=0.83\right)$, spiders $\left(\mathrm{y}=0.02+0.001 \mathrm{x}-6.35^{*} 10^{-7} \mathrm{x}^{2} ; \mathrm{R}^{2}=0.67\right)$ and ladybird beetles $\left(y=0.11+0.01 x ; R^{2}=0.51\right)$ were registered for aphids. No correlation $(\mathrm{P}>0.05)$ was found between Syrphus sp. (Diptera: Syrphidae) (0.01 0.01/leaf) and Chrysoperla sp. (Neuroptera: Chrysopidae) (0.15 \pm 0.13/ leaf) and aphid populations.
A higher number of apterous/leaf and mummified aphids (number/leaf and percentage) were recorded on the bottom part of the plant canopy, compared to the medium and apical parts (Table 1). Higher leaf areas were observed in the medium part than in the bottom and apical parts of Abelmoschus esculentus (Table 1). Higher density of nonglandular trichomes $/ \mathrm{mm}^{2}$ (100\% of trichomes) was observed in the apical part than in the medium and bottom parts of Abelmoschus esculentus, and in the abaxial than in the adaxial leaf surface (Table 1).

No significant effects $(\mathrm{P}>0.05)$ of plant age, trichome density, leaf organic compounds, leaf $\mathrm{N}$ and $\mathrm{K}$ levels, total rainfall and median temperature on aphid population were observed. A significant correlation $(\mathrm{P}<0.05)$ between trichome density $\left(y=0.35-0.002 x ; R^{2}=0.87\right)$ and leaf $\mathrm{K}$ levels ( $\mathrm{y}=4.07-0.02 \mathrm{x} ; \mathrm{R}^{2}=0.53$ ) was observed as plant age increased (Figure $1 \mathrm{H}, \mathrm{J}$ ). Two peaks were observed in okra plants in both plantation (Figure $1 \mathrm{~L}, \mathrm{M}$ ): the first one, with retention times of $25,504 \mathrm{~min}$, was identified as palmitic acid with SI of $88 \%$, and the second, with 28,285 min, was identified as 11,14,17 eicosatrienoic methyl ester acid with SI of $83 \%$. Higher total ion current (TIC) for the peak 25,504 min were recorded for 46 and 76day-old plants in the first and second plantations, respectively, and for the peak 28,285 min were recorded for 80-day-old plants in both plantations (Figure $1 \mathrm{~L}, \mathrm{M}$ ).

\section{DISCUSSION}

Population increase of apterous aphids caused the appearance of winged individuals of $A$. gossypii and higher number of apterous forms of this insect was observed on leaves with larger areas. On the other hand, lower populations were recorded after leaves were colonized and winged forms of this insect for dispersal were observed, such as related by Byamukama et al. (2004) and Rhainds \& Messing (2005). High abundance of A. gossypii on large leaves of Colocasia esculenta (L.) Schott. and okra plants suggest that host attributes affect the rates of colonization or reproduction of adults (RHAINDS \& MESSING, 2005; SECHSER et al., 2002).

The parasitoids Adialytus spp. were the most important natural enemies for population reduction of $A$. gossypii on both okra plantations with more than $55 \%$ of parasitised aphids in the last plantation. The parasitoids of Braconidae family (RHAINDS \& MESSING, 2005; SAMPAIO et al., 2005), spiders (MEN et al., 2004), Chrysoperla sp. (KABISSA et al., 1996), ladybird beetles (MEN et al., 2004) and Syrphidae larva (SECHSER et al., 2002) are important natural enemies of $A$. gossypii. 

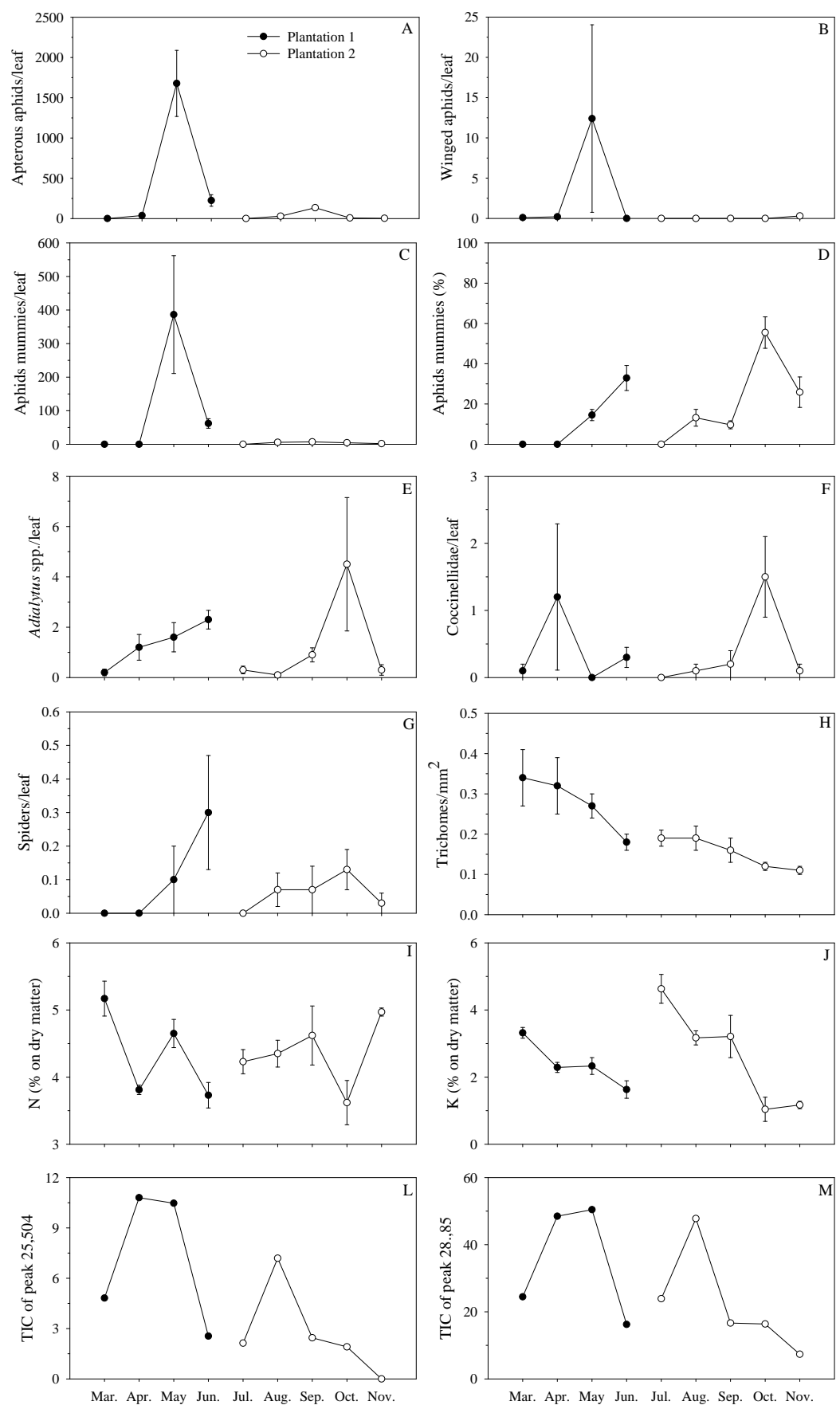

FIGURE 1 - Population dynamics of apterous and winged Aphis gossypii, Adialytus ssp. (number of aphids mummies, $\%$ of aphids mummies and number of adults), Coccinellidae (adults+larvae), spiders (adults+youngs), trichomes (adaxial+abaxial/2), nitrogen and potassium content, total ion curret (TIC) of peaks with retention times of 25,504 and 28,285 min of two Abelmoschus esculentus plantations. The symbols represent the average of 30 leaves for arthropods, three evaluations for the NK content and trichomes and one evaluation for the peaks. Vertical bars indicate standard errors of the mean. Guidoval, MG, 1999.

Ciênc. agrotec., Lavras, v. 31, n. 2, p. 337-343, mar./abr., 2007 
TABLE 1 - Effect of plant canopy on numbers (median \pm standard errors) of apterous Aphis gossypii/leaf, percent of aphid mummies, number of aphid mummies/leaf, trichome density (adaxial + abaxial/2) $\left(\mathrm{mm}^{2}\right)$ and leaf area $\left(\mathrm{cm}^{2}\right)$ in the okra, Abelmoschus esculentus.

\begin{tabular}{|c|c|c|c|}
\hline \multirow[b]{2}{*}{ Variable } & \multicolumn{3}{|c|}{ Plant Canopy } \\
\hline & Apical & Medium & Bottom \\
\hline Aphis gossypii (apterous) & $68.48 \pm 19.27 \mathrm{~B}$ & $462.96 \pm 173.32 \mathrm{AB}$ & $577.52 \pm 149.98 \mathrm{~A}$ \\
\hline Number of aphid mummies & $10.22 \pm 3.57 \mathrm{~B}$ & $103.64 \pm 41.84 \mathrm{AB}$ & $163.60 \pm 68.23 \mathrm{~A}$ \\
\hline Percent of aphid mummies & $13.47 \pm 3.11 \mathrm{~B}$ & $22.05 \pm 3.68 \mathrm{AB}$ & $27.41 \pm 4.26 \mathrm{~A}$ \\
\hline Trichome density & $0.21 \pm 0.06 \mathrm{~A}$ & $0.09 \pm 0.02 \mathrm{~B}$ & $0.10 \pm 0.05 \mathrm{~B}$ \\
\hline \multirow[t]{3}{*}{ Leaf area } & $140.39 \pm 9.99 \mathrm{C}$ & $300.89 \pm 26.32 \mathrm{~A}$ & $226.69 \pm 14.53 \mathrm{~B}$ \\
\hline & \multicolumn{3}{|c|}{ Leaf surface } \\
\hline & Adaxial & & Abaxial \\
\hline Trichome density & $0.08 \pm 0.01 \mathrm{~B}$ & & $0.30 \pm 0.04 \mathrm{~A}$ \\
\hline
\end{tabular}

Means followed by the same letter in the line do not differ by Tukey's multiple range test $(\mathrm{P}<0.05)$.

The lower aphid attack was observed in the second okra plantation, planted $50 \mathrm{~m}$ apart from the first, probably due to the fact that part of the Adialytus spp. (20.8 and 11.9 percentage of aphids mummies/leaf, respectively) population migrated from the first plantation, as well as other natural enemies, increasing proportion natural enemies/aphids in the second okra plantation. Another possibility is that the plants were older (50 days old) and, thus less suitable for this aphids, as observed by Men et al. (2004). At the beginning of the first and second plantations, number of natural enemies (initial colonization phase) was reduced, indicating that these arthropods were latent in nearby areas until okra plants infested with aphids appeared. Men et al. (2004) studied for two years the winter Triticum aestivum $\mathrm{L}$. as a potential relay crop to conserve arthropod natural enemies and suppress A. gossypii in seedling cotton. These authors suggested that the wheat strip served as a reservoir to conserve arthropod predators and relayed its predators to cotton when wheat was reaching maturity and senescence. Another interesting point is the fact that higher numbers of A. gossypii facilitates its location by Adialytus spp. because this parasitoid presented higher percentage of parasitised aphids in the basal than in the apical leaves of okra plants. Rhainds \& Messing (2005) related that the level of parasitism [Aphelinus sp. (Hymenoptera: Aphelinidae) and Aphidius sp. (Hymenoptera: Braconidae)] among $A$. gossypii on Colocasia esculenta (L.) Schott. decreased from old to young leaves, and was lower on sentinel plants than on established plants. Mechanisms underlying variations in the intensity of parasitism may include an enhanced foraging activity of parasitoids on old leaves, as well as limited impact of parasitism on plants recently colonized by aphids (RHAINDS \& MESSING, 2005).

Although no significant effects $(\mathrm{P}>0.05)$ of plant age, total rainfall and median temperature on aphid population were observed, in June and October, when plants were 86 and 140 days old respectively, there was a drastic decrease in the insect population, probably due to, besides natural enemies, plant senescence and/or associated with rainy season (total rainfall = March: $189 \mathrm{~mm}$, April: $25 \mathrm{~mm}$, May: $0 \mathrm{~mm}$, June: $24 \mathrm{~mm}$, July: $0 \mathrm{~mm}$, August: $0 \mathrm{~mm}$, September: $32 \mathrm{~mm}$, October: $125 \mathrm{~mm}$ and November: 509 $\mathrm{mm})$. High rainfall is an important mortality factor of $A$. gossypii in the field (MCDONALD et al., 2003; RHAINDS $\&$ MESSING, 2005) and this insect is considered to be initial pest due to changes in plant quality as the crop gets older (MEN et al., 2004; RHAINDS \& MESSING, 2005; SANTOS et al., 2003; SOGLIA et al., 2002).

The A. gossypii population attack preferentially in young leaves, which are generally located on the apical parts (CHAU et al., 2005; SANTOS et al., 2003). However, in the present study, we observed higher attack of this insect in the bottom and medium rather than in the apical part of okra plants. A plausible explanation, besides leaf areas (RHAINDS \& MESSING, 2005; SECHSER et al., 2002), for the non-occurrence of attack preferentially on the apical leaves is that these leaves have more trichomes, which can 
make locomotion, feeding and reproduction of A. gossypii difficult (SANTOS et al., 2003; SOGLIA et al., 2002, 2003), despite the absence of significant relationship between them.

The leaf organic compounds were not correlated ( $\mathrm{P}>0.05$ ) with aphid population. The 11,14,17 eicosatrienoic methyl ester acid, identified in the hexane extractus using the mass spectral data base, has not been reported for okra. However, palmitic acid was related in the seed oil content (28\%) of okra (CAMCIUC et al., 1998) and this organic compound was the major fatty acid in triacylglycerols, principally in winged virginoparae of Aphis fabae Scopoli (Hemiptera: Aphididae) (ITUYAMA et al., 2000). There were significantly less triacylglycerols in wingless than in winged forms (ITOYAMA et al., 2000). The amount of lipid in these winged aphid forms may be associated with energy requirements for flight (ITOYAMA et al., 2000). Although these compounds were identified with a high SI, their identification should be confirmed by other methods. For this, it is necessary to isolate these compounds in large quantities and identify them through more precise spectroscopic methods.

Although nutritional, chemical and morphological changes in plants have been reported to affect A. gossypii populations in cotton, wheat, $C$. esculenta, Dendranthema grandiflora Tzvelev. (CHAU et al., 2005; MEN et al., 2004; RHAINDS \& MESSING, 2005; SANTOS et al., 2003; SOGLIA et al., 2002, 2003), leaf $\mathrm{N}$ and K, leaf organic compounds analyzed and trichomes were apparently not important in this study. The trichomes (\% non-glandular) found in okra were of low density and did not contain toxic compounds, which could present antibiotic and nonpreference effects. This was expected because this okra cultivar has been selected for a long time to maximise productivity of fruits, which reduces the frequency of glandular trichomes and its resistance against attack by herbivore arthropods. The NK fertilization can affect the degree of attack by insects. An excess of $\mathrm{N}$ and deficiency in $\mathrm{K}$ have been reported to lead to higher accumulation of amino acids in plants and a higher degree of attack by aphids, such as A. gossypii (CHAU et al., 2005; CISNEROS \& GODFREY, 2001; NEVO \& COLL, 2001). The effects of leaf $\mathrm{N}$ and $\mathrm{K}$ levels in okra an aphid population were not detected due to the small variation of these nutrients in the leaves during the experimental period.

\section{CONCLUSION}

Aphid population in okra is affected by crop senescence, plant canopy, leaf areas and natural enemies.
Aphis gossypii can be a harmful pest in okra producing regions of lower total rainfall. Apparently, non-glandular trichomes or their low density, organic compounds in the leaves and levels of $\mathrm{N}$ and $\mathrm{K}$ are not correlated with aphid population.

\section{REFERENCES}

BYAMUKAMA, E.; GIBSON, R. W.; ARITUA, V.; ADIPALA, E. Within-crop spread of sweet potato virus disease and the population dynamics of its whitefly and aphid vectors. Crop Protection, London, v. 23, n. 2, p. 109116, 2004.

CAMCIUC, M.; DEPLAGNE, M.; VILAREM, G.; GASET, A. Okra - Abelmoschus esculentus L. (Moench.) a crop with economic potential for set aside acreage in France. Industrial Crops and Products, Amsterdam, v. 7, n. 2/3, p. 257-264, 1998.

CHAU, A.; HEINZ, M.; DAVIES JUNIOR, F. T. Influences of fertilization on Aphis gossypii and insecticide usage. Journal of Applied Entomology, Berlin, v. 129, n. 2, p. 89-97, 2005.

CISNEROS, J. J.; GODFREY, L. D. Midseason pest status of the cotton aphid (Homoptera: Aphididae) in California cotton: is nitrogen a key factor? Environmental Entomology, Lanham, v. 30, n. 3, p. 501-510, 2001.

DENT, D. R. Integrated pest management. London: Chapman and Hall, 1995. 356 p.

FILGUEIRA, F. A. R. Novo manual de olericultura. Viçosa: UFV, 2000. 402 p.

HOROWITZ, A. R. Control strategy for the sweetpotato whitefly, Bemisia tabaci, late in the cotton-growing season. Phytoparasitica, Rehovot, v. 21, n. 4, p. 281-291, 1993.

ITOYAMA, K.; TOJO, S.; YANAGITA, T.; HARDIE, J. Lipid composition in long-day and short-day forms of the black bean aphid, Aphis fabae. Journal of Insect Physiology, Oxford, v. 46, n. 2, p. 119-125, 2000.

JACKSON, M. L. Soil chemical analysis. New Jersey: Prentice Hall, 1958. 498 p.

JANSSON, J.; EKBOM, B. The effect of different plant nutrient regimes on the aphid Macrosiphum euphorbiae growing on petunia. Entomologia Experimentalis et Applicata, Dordrecht, v. 104, n. 1, p. 109-116, 2002. 
KABISSA, J. C. B.; KAYUMBO, H. Y.; YARRO, J. G. Seasonal abundance of chrysopids (Neuroptera chrysopidae) preying on Helicoverpa armigera (Hubner) (Lepidoptera: Noctuidae) and Aphis gossypii (Glover) (Homoptera: Aphididae) on cotton in eastern Tanzania. Crop Protection, London, v. 15, n. 1, p. 5-8, 1996.

McDONALD, S. A.; HALBERT, S. E.; TOLIN, S. A.; NAULT, B. A. Seasonal abundance and diversity of aphids (Homoptera: Aphididae) in a pepper production region in Jamaica. Environmental Entomology, Lanham, v. 32, n. 3, p. 499-509, 2003.

MEN, X. Y.; GE, F.; YARDIM, E. N.; PARAJULEE, M. N. Evaluation of winter wheat as a potential relay crop for enhancing biological control of cotton aphids in seedling cotton. BioControl, Dordrecht, v. 49, n. 6, p. 701-714, 2004.

NEVO, E.; COLL, M. Effect of nitrogen fertilization on Aphis gossypii (Homoptera: Aphididae): variation in size, color and reproduction. Journal of Economical Entomology, Lanham, v. 94, n. 1, p. 27-32, 2001.

PATEL, K. I.; PATEL, J. R.; JAYANI, D. B.; SHEKH, A. M.; PATELS, N. C. Effect of seasonal weather on incidence and development of major pests of okra (Abelmoschus esculentus). Indian Journal of Agricultural Sciences, New Delhi, v. 67, n. 5, p. 181-183, 1997.

RHAINDS, M.; MESSING, R. H. Spatial and temporal density dependence in a population of melon aphid, Aphis gossypii Glover (Homoptera: Aphididae), on established and sentinel taro plants. Applied and Entomology and Zoology, Tokio, v. 40, n. 2, p. 273-282, 2005.

SAMPAIO, M. V.; BUENO, V. H. P.; RODRIGUES, S. M. M.; SOGLIA, M. C. M. Resposta à temperatura de Aphidius colemani Viereck (Hymenoptera, Braconidae, Aphidiinae) originário de três regiões climáticas de Minas Gerais, Brasil. Revista Brasileira de Entomologia, São Paulo, v. 49, n. 1, p. 141-147, 2005.

SANTOS, T. M.; BOIÇA JÚNIOR, A. L.; SOARES, J. J. Influência de tricomas do algodoeiro sobre os aspectos biológicos e capacidade predatória de Chrysoperla externa (Hagen) alimentada com Aphis gossypii Glover. Bragantia, Campinas, v. 62, n. 2, p. 243-254, 2003.

SATAR, S.; KERSTING, U.; UYGUN, N. Effect of temperature on development and fecundity of Aphis gossypii Glover (Homoptera: Aphididae) on cucumber. Journal of Pest Science, Heidelberg, v. 78, n. 3, p. 133-137, 2005.

SECHSER, B.; REBER, B.; BOURGEOIS, F. Pymetrozine: selectivity spectrum to beneficial arthropods and fitness for integrated pest management. Journal of Pest Science, Heidelberg, v. 75, n. 3, p. 72-77, 2002.

SLOSSER, J. E.; PARAJULEE, M. N.; HENDRIX, D. L.; HENNEBERRY, T. J.; PINCHAK, W. E. Cotton aphid (Homoptera: Aphididae) abundance in relation to cotton leaf sugars. Environmental Entomology, Lanham, v. 33, n. 3, p. 690-699, 2004.

SOGLIA, M. C. M.; BUENO, V. H. P.; RODRIGUES, S. M. M.; SAMPAIO, M. V. Fecundidade e longevidade de Aphis gossypii Glover, 1877 (Hemiptera: Aphididae) em diferentes temperaturas e cultivares comerciais de crisântemo (Dendranthema glandiflora Tzvelev). Revista Brasileira de Entomologia, São Paulo, v. 47, n. 1, p. 49-54, 2003.

SOGLIA, M. C. M.; BUENO, V. H. P.; SAMPAIO, M. V. Desenvolvimento e sobrevivência de Aphis gossypii Glover (Hemiptera: Aphididae) em diferentes temperaturas e cultivares comerciais de crisântemo. Neotropical Entomoloty, Londrina, v. 31, n. 2, p. 211-216, 2002. 